\title{
Biosynthesized ZnO Nanoparticles Using Albizia lebbeck Extract Induced Biochemical and Morphological Alterations in Wistar Rats
}

\author{
Doga Kavaz 1,2,*(D), Amina Lawan Abubakar ${ }^{1,3}$, Nahit Rizaner 1,2 and Huzaifa Umar 1,2 (D) \\ 1 Bioenginering Department, Faculty of Engineering, Cyprus International University, Via Mersin 10, \\ Nicosia 98258, Northern Cyprus, Turkey; suhay1994@gmail.com (A.L.A.); nrizaner@ciu.edu.tr (N.R.); \\ humar@ciu.edu.tr (H.U.) \\ 2 Biotechnology Research Centre, Cyprus International University, Via Mersin 10, \\ Nicosia 99258, Northern Cyprus, Turkey \\ 3 Department of Biochemistry, Kano State University of Science and Technology, Wudil, \\ Kano P.M.B 3244, Nigeria \\ * Correspondence: dkavaz@ciu.edu.tr; Tel.: +90-3926711111
}

Citation: Kavaz, D.; Abubakar, A.L.; Rizaner, N.; Umar, H. Biosynthesized ZnO Nanoparticles Using Albizia lebbeck Extract Induced Biochemical and Morphological Alterations in Wistar Rats. Molecules 2021, 26, 3864. https://doi.org/10.3390/

molecules26133864

Academic Editor: Nadine Millot

Received: 11 May 2021

Accepted: 17 June 2021

Published: 24 June 2021

Publisher's Note: MDPI stays neutral with regard to jurisdictional claims in published maps and institutional affiliations.

Copyright: (c) 2021 by the authors. Licensee MDPI, Basel, Switzerland. This article is an open access article distributed under the terms and conditions of the Creative Commons Attribution (CC BY) license (https:// creativecommons.org/licenses/by/ $4.0 /)$.

\begin{abstract}
Nano-based particles synthesized via green routes have a particular structure that is useful in biomedical applications as they provide cheap, eco-friendly, and non-toxic nanoparticles. In the present study, we reported the effect of various concentrations of Zinc oxide nanoparticles synthesized using $A$. lebbeck stem bark extract (ZnO NPsAL) as stabilizing agent on rat biochemical profiles and tissue morphology. Adult Wistar rats weighing $170 \pm 5 \mathrm{~g}$ were randomly classified into eight groups of five rats each; Group A served as a control fed with normal diet and water. Groups B1, B2, C1, C2, D1, D2, and E were treated with $40 \mathrm{mg} / \mathrm{kg}$ and $80 \mathrm{mg} / \mathrm{kg}$ of the $0.01,0.05$, and $0.1 \mathrm{M}$ biosynthesized ZnO NPsAL and zinc nitrate daily by the gavage method, respectively. The rats were anesthetized $24 \mathrm{~h}$ after the last treatment, blood samples, kidney, heart, and liver tissues were collected for biochemical and histopathological analysis. The rats mean body weight, serum alkaline phosphatase, alanine aminotransferase, creatinine, urea, bilirubin, protein, albumin, globulin, total cholesterol, triacylglycerol, and high-density lipoprotein were significantly altered with an increased concentration of biosynthesized ZnO NPsAL when compared with the control group $(p<0.05$; $n \geq 5$ ). Furthermore, histopathological analysis of treated rats' kidney, heart, and liver tissue revealed vascular congestion, tubular necrosis, inflammation, and cytoplasmic vacuolation. Biosynthesized ZnO NPsAL showed significant alteration in biochemical parameters and tissue morphology in rats with increasing concentrations of the nanoparticles.
\end{abstract}

Keywords: biomedical applications; stabilizing agent; kidney; heart; liver; protein

\section{Introduction}

Nanotechnology is an advanced area of studies that utilizes environmentally friendly technologies to synthesize nanoparticles, which are chemically stable, non-toxic, biocompatible, and can be used for biomedical applications [1]. Nanomaterials are smaller-sized particles in the nanoscale dimension with good thermal conductivity, improved catalytic reactivity, and chemical steadiness because of the large surface area [2]. Metal nanoparticles are toxic, difficult to synthesize, expensive, stabilizing agents used in synthesis, and naturally antagonistic [3]. Nano-based particles via green routes have particular structurespecific usefulness in biomedical applications as they provide cheap, eco-friendly, and non-toxic nanoparticles [4]. The surface charge present on nanoparticles contributes to their absorption. Studies revealed ZnO NPs with positively charged ions to be less toxic due to their lower absorption efficiency than those with negatively charged ions [5]. Zinc oxide nanoparticles (ZnO NPs) also have all the properties exhibited by all nanoparticles. It could be used in electronics, biosensors, cosmetics, environmental protection, biology, 
and the medicinal industry (Rasmussen et al., 2010). ZnO NPs are characterized by their photo-oxidizing and photocatalytic activity against biological and chemical species [3] In addition, $\mathrm{ZnO}$ was recognized by the US Food and Drug Administration (FDA) as a generally safe and recognized substance [5].

Hence, $\mathrm{ZnO}$ NPs are attractive to many researchers because zinc is the most crucial trace metal found in the human body after iron. It activates many enzymes in the body and regulates blood sugar levels and diverse metabolic activities [6]. Furthermore, diseases such as chronic liver diseases and malabsorption syndrome happened due to homeostasis deviation and zinc deficiency [7]. Synthesis of ZnO NPs via green routes is one of the most straightforward methods, cost-effective, and viable with novel properties than other biosynthesized metal nanoparticles [8]. Some leaves and stem bark extracts used in the synthesis of ZnO NPs include Costus pictus D. Don [9], Parthenium hysterophorus L. [10], and $A$. lebbeck [11]. Studies report bio-extract-mediated $\mathrm{ZnO}$ nanoparticles with exclusive properties revealed novel alternatives to cancer therapy, anti-diabetic, antioxidant, and anti-microbial activity $[12,13]$.

Albizia lebbeck is a fast-growing deciduous tree with an open, large, spreading crown; it usually reaches $15-20 \mathrm{~m}$ high, with exceptional specimens growing up to $30 \mathrm{~m}$ high. The straight, cylindrical bole with impressive specimens up to $300 \mathrm{~cm}$ can be $50-100 \mathrm{~cm}$ in diameter [14] Saponin isolated from A. lebbeck stem bark revealed intense cytotoxic activity against human aqueous cell carcinoma (HSC-2 and HSC-3) [15]. Three Flavonoids (Isookanin, geraldone, and 5-deoxyflavone) isolated from the plant methanolic extract bark revealed antioxidant and anti-diabetic activity in vitro [16].

In the present study, we reported the effect of novel Zinc oxide nanoparticles synthesized using A. lebbeck stem extract (ZnO NPsAL) as a stabilizing agent in Wistar rats. The impact of the biosynthesized ZnO NPS on rats body weight and metabolic profile such Alkaline Phosphatase (ALP), Alanine Aminotransferase (ALT), Aspartate Aminotransferase (AST), Creatinine (CREA), Urea, Bilirubin (BIL), Total Cholesterol (TC), Triacylglycerols (TG), High-Density Lipoprotein (HDL-C), total Protein, Albumin ALB and Globulin (GLB). Furthermore, Histopathological examinations of the kidney, heart, and liver of the treated and control rats were also carried out.

\section{Results}

\subsection{Average Weight of the Animals}

The effect of various concentrations of ZnO NPs synthesized using A. lebbeck stem bark aqueous extract was studied on the average weight of experimental animals after 28 days of oral administration (Figure 1). The average body weights of all the experimental groups were quite similar at the initial stage of the experiments. Following 28 days of exposure to synthesized $\mathrm{ZnO}$ NPs, the weight of all the concentrations (B1-D2) administered to the animals significantly decreased with increased concentrations when compared with the control groups ( $p<0.05 ; n \geq 5$; Figure 1 ). The mean body weight of the control group increased by $10 \%$ after the 28 days treatment period (Figure 1), and no harmful sign or mortality was observed in all the groups.

\subsection{Biochemical Parameters Analysis}

The effects of various concentrations of synthesized ZnO NPsAL on serum level markers of liver function were reported in Table 1. The level of ALP decreased with increased concentrations of the synthesized zinc oxide nanoparticles and $0.1 \mathrm{M} \mathrm{ZnO} \mathrm{NPsAL}$ (40 $\mathrm{mg} \mathrm{kg}^{-1}$ and $80 \mathrm{mg} \mathrm{kg}^{-1}$ ) and significantly decreased ALP level when compared with the control group ( $p<0.05 ; n \geq 5$; Table 1). The ALT level increased with increased ZnO NPsAL concentrations, and all the concentrations revealed significant differences compared with the control group $(p<0.05 ; n \geq 5$; Table 1). Furthermore, no significant difference was observed in all the concentrations of ZnO NPsAL on AST ( $p>0.05 ; n \geq 5$; Table 1). 


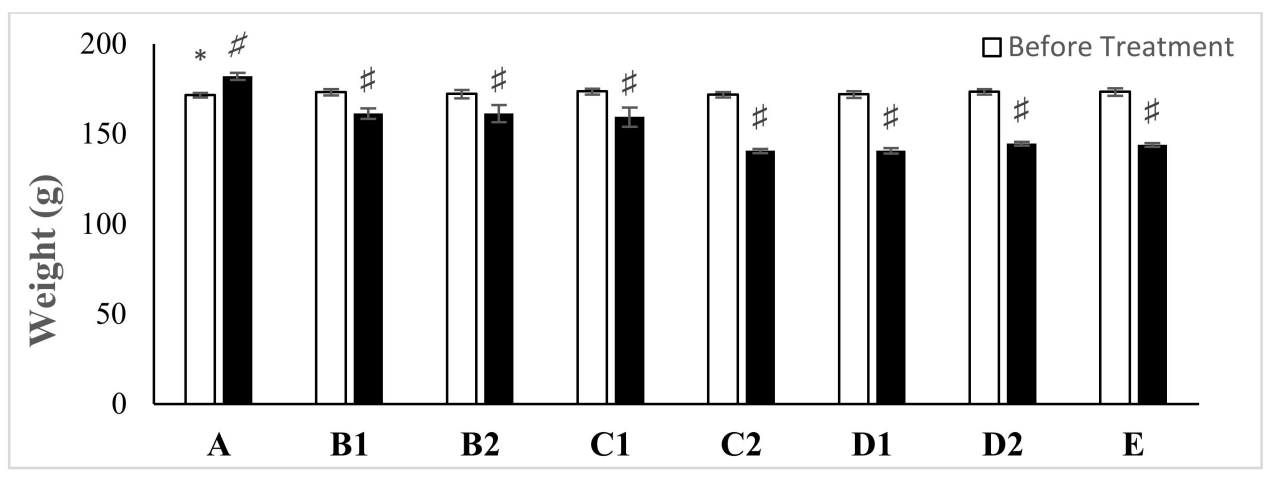

Figure 1. Mean body weight of experimental animals before and after oral administration of various concentrations of ZnO NPs Al. Data are presented as the mean \pm SEM of at least $n \geq 5$ replicate experiments and analyzed using one-way ANOVA followed by Newman-Keuls post hoc analysis. $\left(^{*}\right) p<0.05 ;\left(^{\sharp}\right) p<0.05$. Abbreviations: A, Control; B1, $0.01 \mathrm{M} \mathrm{ZnO} \mathrm{NPsAL}\left(80 \mathrm{mg} \mathrm{kg}^{-1}\right)$; B2, $0.01 \mathrm{M} Z \mathrm{ZnO}$ NPsAL (40 mg kg-1); C1, $0.05 \mathrm{M}$ ZnO NPsAL (80 $\left.\mathrm{mg} \mathrm{kg}^{-1}\right)$; C2, 0.05M ZnO NPsAL (40 mg kg $\left.{ }^{-1}\right)$; D1, 0.1 M ZnO NPsAL (80 $\left.\mathrm{mg} \mathrm{kg}^{-1}\right)$; D2, $\left.0.1 \mathrm{M} \mathrm{ZnO} \mathrm{NPsAL} \mathrm{(40} \mathrm{mg} \mathrm{kg}{ }^{-1}\right)$; E, Zinc nitrate solution $\left(80 / 40 \mathrm{mg} \mathrm{kg}^{-1}\right)$.

Table 1. The effect of various concentration of biosynthesized ZnO NPsAL on ALP, ALT, and AST concentrations in rats.

\begin{tabular}{|c|c|c|c|c|c|c|}
\hline \multirow{2}{*}{$\begin{array}{l}\text { Group } \\
\text { Control }\end{array}$} & \multicolumn{2}{|c|}{$\begin{array}{c}\text { ALP } \\
(\mathrm{U} / \mathrm{L})\end{array}$} & \multicolumn{2}{|c|}{$\begin{array}{c}\text { ALT } \\
\text { (U/L) }\end{array}$} & \multicolumn{2}{|c|}{$\begin{array}{c}\text { AST } \\
\text { (U/L) }\end{array}$} \\
\hline & 37.60 & \pm 4.1 & 3.80 & \pm 0.5 & 11.20 & \pm 0.7 \\
\hline 0.01M ZnO NPsAL (80 $\left.\mathrm{mg} \mathrm{kg}^{-1}\right)$ & 37.00 & \pm 7.4 & 6.20 & $\pm 0.5^{*}$ & 12.40 & \pm 1.1 \\
\hline 0.01M ZnO NPsAL (40 $\left.\mathrm{mg} \mathrm{kg}^{-1}\right)$ & 36.40 & \pm 2.1 & 6.00 & $\pm 0.5^{*}$ & 11.80 & \pm 0.7 \\
\hline 0.05M ZnO NPsAL (80 $\left.\mathrm{mg} \mathrm{kg}^{-1}\right)$ & 31.60 & \pm 6.8 & 7.00 & \pm 0.9 * & 12.40 & \pm 1.1 \\
\hline 0.05M ZnO NPsAL (40 $\left.\mathrm{mg} \mathrm{kg}^{-1}\right)$ & 33.20 & \pm 4.1 & 6.20 & $\pm 0.5^{*}$ & 11.20 & \pm 0.7 \\
\hline $0.1 \mathrm{M} \mathrm{ZnO}$ NPsAL $\left(80 \mathrm{mg} \mathrm{kg}^{-1}\right)$ & 11.80 & $\pm 3.4 *$ & 6.80 & \pm 0.5 * & 13.00 & \pm 0.9 \\
\hline 0.1M ZnO NPsAL (40 mg kg $\left.\mathrm{mg}^{-1}\right)$ & 23.40 & $\pm 6.6^{*}$ & 6.80 & \pm 1.0 * & 11.20 & \pm 0.7 \\
\hline Zinc nitrate solution & 34.20 & \pm 6.0 & 6.20 & $\pm 0.5^{*}$ & 10.00 & \pm 0.9 \\
\hline
\end{tabular}

Data are presented as the mean \pm SEM of at least $n \geq 5$ replicate experiments and analyzed using one-way ANOVA followed by Newman-Keuls post hoc analysis. $\left.{ }^{*}\right) p<0.05$.

Effects of various concentrations of synthesized $\mathrm{ZnO}$ NPsAL on serum creatinine, urea, total bilirubin, and direct bilirubin were determined (Figure 2A,B) following 28 days of oral exposure. Oral administration of synthesized ZnO NPsAL altered serum creatinine and urea level in rats, and $0.05 \mathrm{M} Z \mathrm{ZnO}$ NPsAL revealed significant serum creatinine levels relative to the control ( $p<0.05 ; n \geq 5$; Figure 2A). In addition, zinc nitrate solution (40 mg kg $\mathrm{g}^{-1}$ and $80 \mathrm{mg} \mathrm{kg}^{-1}$ ) significantly decreased creatinine and urea serum level concentrations $(p<0.05 ; n \geq 5$; Figure 2A). Furthermore, serum total and direct bilirubin level significantly increased with an increase in the concentration of the particles, $0.01 \mathrm{M}$ and $0.05 \mathrm{M}$ revealed a significant difference when compared with the control group, whereas $0.1 \mathrm{M}$ did not reveal any significant difference when compared with the control group ( $p>0.05 ; n \geq 5$; Figure 2B). 


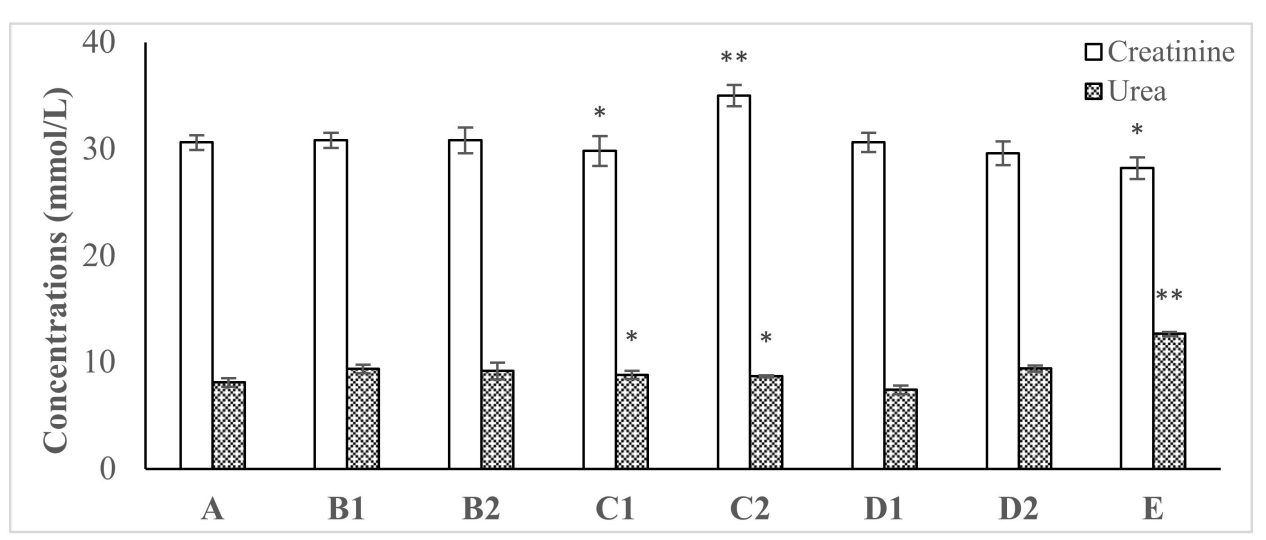

(A)

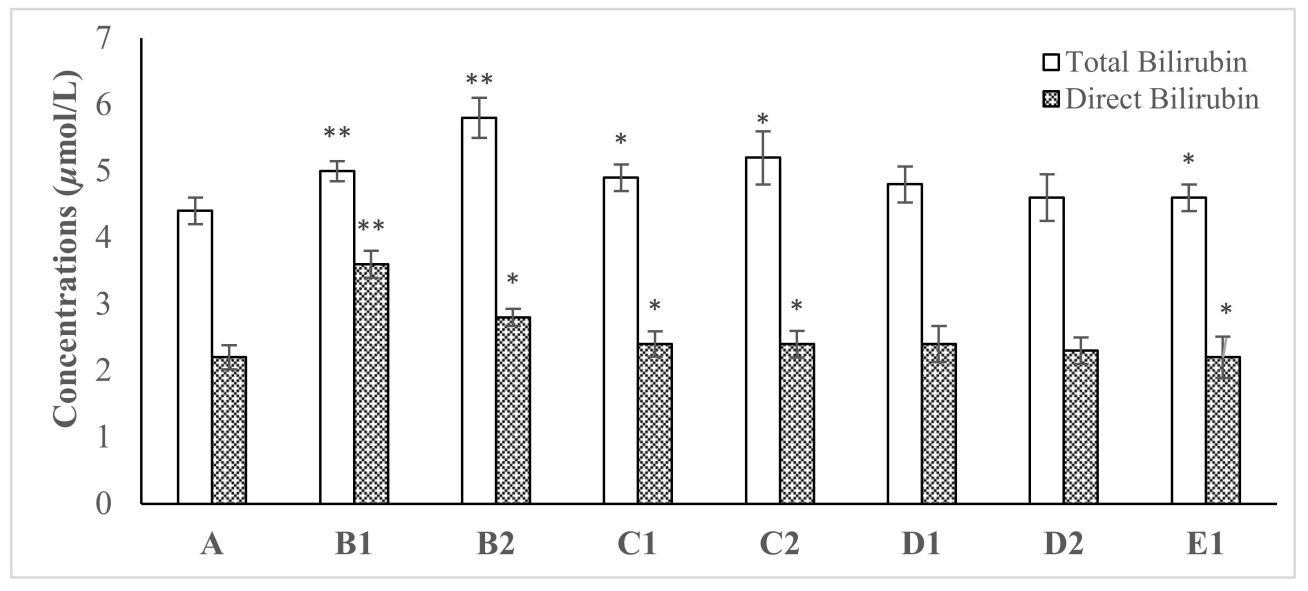

(B)

Figure 2. The effect of various concentrations of biosynthesized ZnO NPsAL on serum concentrations in rats (A) creatinine and urea (B) total bilirubin and direct bilirubin. Data are presented as mean \pm SEM of at $n \geq 5$ least replicate experiments and analyzed using one-way ANOVA followed by Newman-Keuls post hoc analysis. $\left(^{*}\right) p<0.05$; $\left(^{* *}\right) p<0.01$; Abbreviations: A, Control; B1, 0.01M ZnO NPsAL (80 mg kg $\left.{ }^{-1}\right)$; B2, $0.01 \mathrm{M}$ ZnO NPsAL (40 $\left.\mathrm{mg} \mathrm{kg}^{-1}\right)$; C1, $0.05 \mathrm{M}$ ZnO NPsAL (80 $\left.\mathrm{mg} \mathrm{kg}^{-1}\right)$; C2, $0.05 \mathrm{M}$ ZnO NPsAL (40 $\left.\mathrm{mg} \mathrm{kg}^{-1}\right)$; D1, $0.1 \mathrm{M} \mathrm{ZnO} \mathrm{NPsAL} \mathrm{(80} \mathrm{mg} \mathrm{kg}^{-1}$ ); D2, $0.1 \mathrm{M}$ ZnO NPsAL (40 $\left.\mathrm{mg} \mathrm{kg}^{-1}\right)$; E, Zinc nitrate solution (80/40 $\left.\mathrm{mg} \mathrm{kg}^{-1}\right)$.

The effect of various concentrations of synthesized ZnO NPsAL on rat serum protein, albumin, and globulin (Figure $3 ; n \geq 5$ ) following 28 days oral exposure was not significant in all concentrations and zinc nitrate solution except $0.05 \mathrm{M}$ ZnO NPsAL when compared with the control ( $p<0.05 ; n \geq 5$; Figure 3). In contrast, the serum level of total protein and globulin was elevated with all the concentrations compared with the control group (Figure $3 ; n \geq 5$ ). 


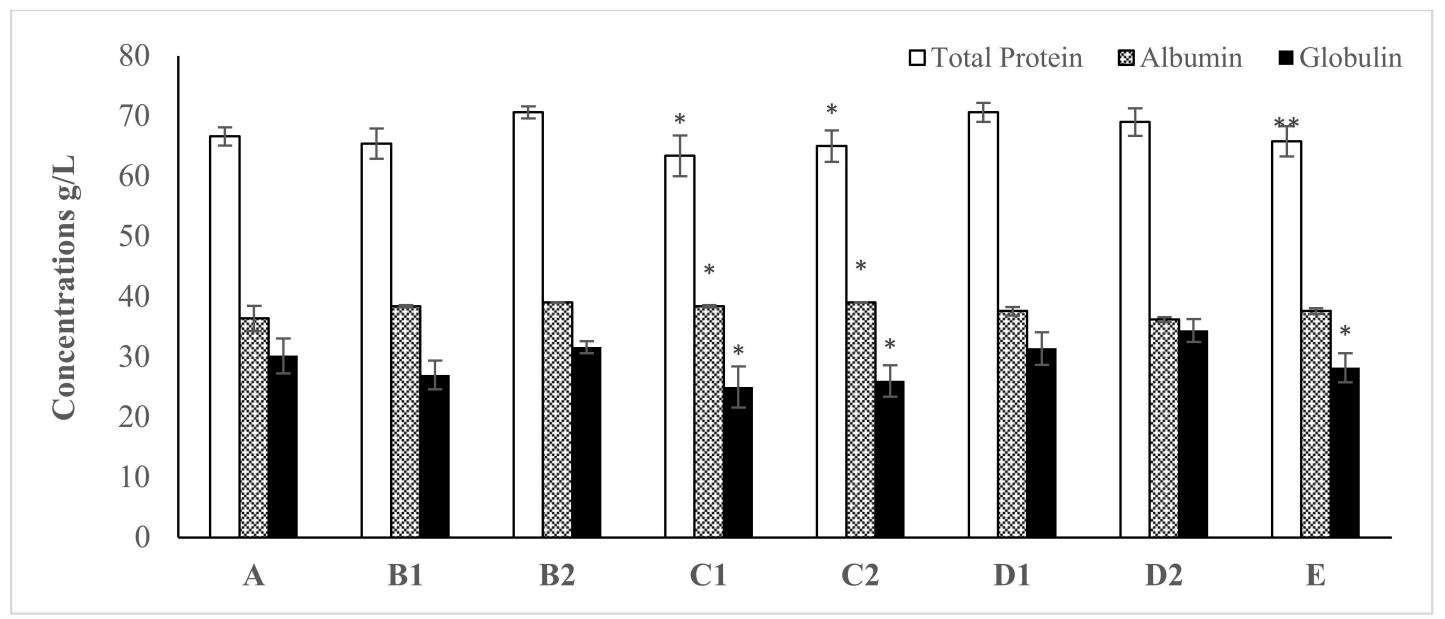

Figure 3. The effect of various concentrations of biosynthesized ZnO NPsAL on total protein albumin and globulin concentrations in rats. Data are presented as the mean \pm SEM of at least $n \geq 5$ replicate experiments and analyzed using one-way ANOVA followed by Newman-Keuls post hoc analysis. $\left(^{*}\right) p<0.05 ;\left(^{* *}\right) p<0.01$. Abbreviations: A, Control; B1, 0.01 M ZnO NPsAL (80 mg kg ${ }^{-1}$ ); B2, $0.01 \mathrm{M}$ ZnO NPsAL (40 mg kg-1); C1, $\left.0.05 \mathrm{M} \mathrm{ZnO} \mathrm{NPsAL} \mathrm{(80} \mathrm{mg} \mathrm{kg}{ }^{-1}\right)$; C2, $0.05 \mathrm{M}$ ZnO NPsAL (40 mg kg-1); D1, $0.1 \mathrm{M} \mathrm{ZnO} \mathrm{NPsAL} \mathrm{(80} \mathrm{mg} \mathrm{kg}^{-1}$ ); D2, $0.1 \mathrm{M} \mathrm{ZnO} \mathrm{NPsAL} \mathrm{(40} \mathrm{mg} \mathrm{kg-1);} \mathrm{E,} \mathrm{Zinc} \mathrm{nitrate}$ solution $\left(80 / 40 \mathrm{mg} \mathrm{kg}^{-1}\right)$.

Synthesized ZnO NPsAL changed the rat lipid profiles following 28 days of oral exposure (Figure 4). The total cholesterol level increased in all concentrations at $40 \mathrm{mg} \mathrm{kg}^{-1}$ and decreased at $80 \mathrm{mg} \mathrm{kg}^{-1}$ as compared with the control group. Furthermore, HDL, TG, and LDL were also significantly increased in all treated groups.

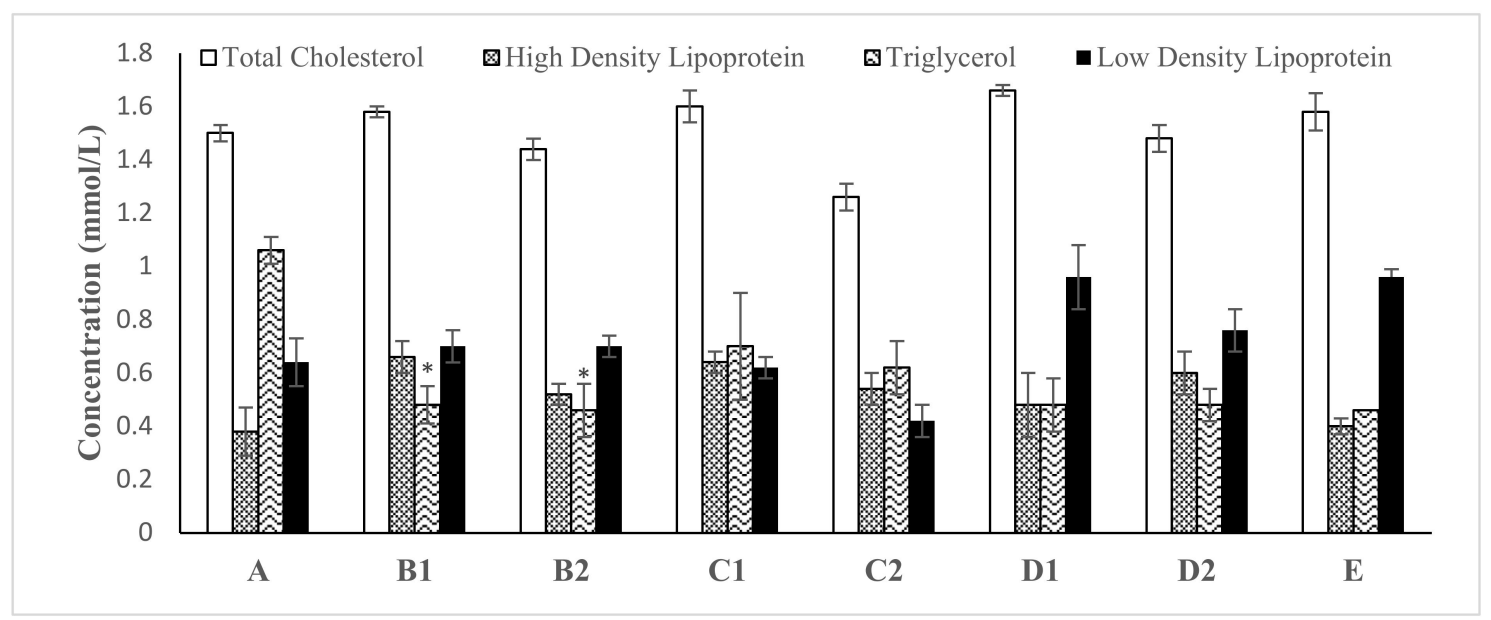

Figure 4. The effect of various concentrations of biosynthesized ZnO NPsAL on TC, HDL, TG, and LDL concentrations in rats. Data are presented as the mean \pm SEM of at least $n \geq 5$ replicate experiments and analyzed using one-way ANOVA followed by Newman-Keuls post hoc analysis. $\left.{ }^{*}\right) p<0.05$; Abbreviations: A, Control; B1, $\left.0.01 \mathrm{M} \mathrm{ZnO} \mathrm{NPsAL} \mathrm{(80} \mathrm{mg} \mathrm{kg}{ }^{-1}\right)$; B2, 0.01 M ZnO NPsAL (40 mg kg-1); C1, $0.05 \mathrm{M}$ ZnO NPsAL (80 mg kg-1); C2, $\left.0.05 \mathrm{M} \mathrm{ZnO} \mathrm{NPsAL} \mathrm{(40} \mathrm{mg} \mathrm{kg}{ }^{-1}\right)$; D1, $0.1 \mathrm{M} Z \mathrm{ZnO}$ NPsAL (80 mg kg-1); D2, 0.1 M ZnO NPsAL (40 $\left.\mathrm{mg} \mathrm{kg}^{-1}\right)$; E, Zinc nitrate solution $\left(80 / 40 \mathrm{mg} \mathrm{kg}^{-1}\right)$.

\subsection{Histopathological Examinations}

Histopathological investigations of rat renal, cardiac, and hepatic tissue following 28 days repeated oral exposure to various concentrations of biosynthesized ZnO NPsAL. The photomicrograph of rats renal tissue treated with 40 and $80 \mathrm{mg} \mathrm{kg}^{-1}$ of 0.05 and $0.1 \mathrm{M}$ $\mathrm{ZnO}$ NPsAL showed vascular congestion, inflammation, necrosis, and desquamation of renal epithelium, whereas the control, $0.01 \mathrm{M} \mathrm{ZnO} \mathrm{NPsAL}$ and $\mathrm{Zn}\left(\mathrm{NO}_{3}\right)_{2}$ groups revealed intact tissue morphology without any cellular or tissue damage (Figure 5a; Table 2). Intact 
cardiac tissue morphology was observed in all the groups treated with various concentrations of biosynthesized ZnO NPs and the control (Figure 5b; Table 2). Furthermore, significant morphological changes such as Cytoplasmic vacuolation and Periportal inflammation were observed in hepatic tissue of rats treated with 40 and $80 \mathrm{mg} \mathrm{kg}^{-1}$ of $0.01,0.05$, and $0.1 \mathrm{M} \mathrm{ZnO} \mathrm{NPsAL} \mathrm{(Figure} 5 \mathrm{c}$; Table 2). The $\mathrm{Zn}\left(\mathrm{NO}_{3}\right)_{2}$ and the control group revealed intact tissue morphology without any cellular or tissue damage (Figure 5).

A.

B.
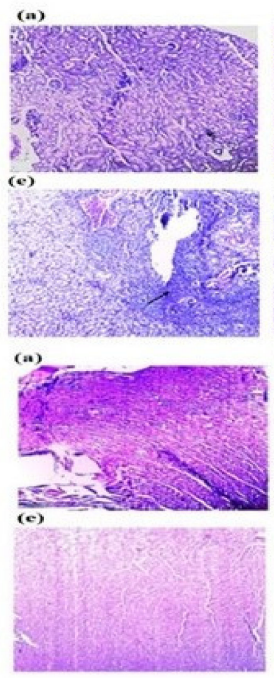

C.
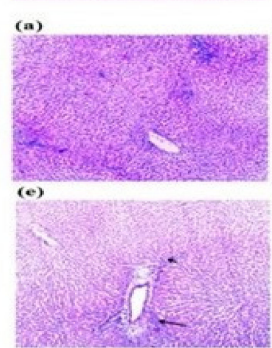
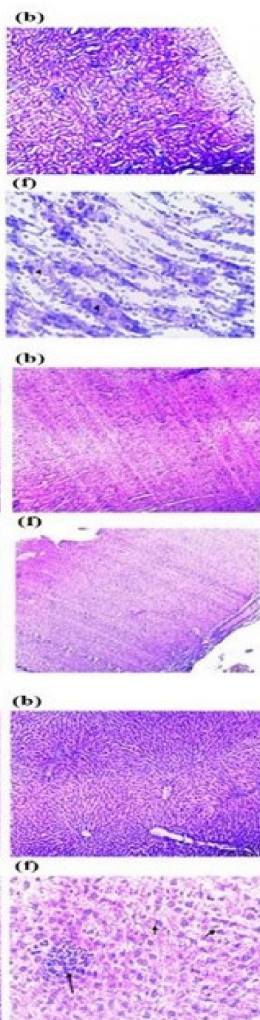
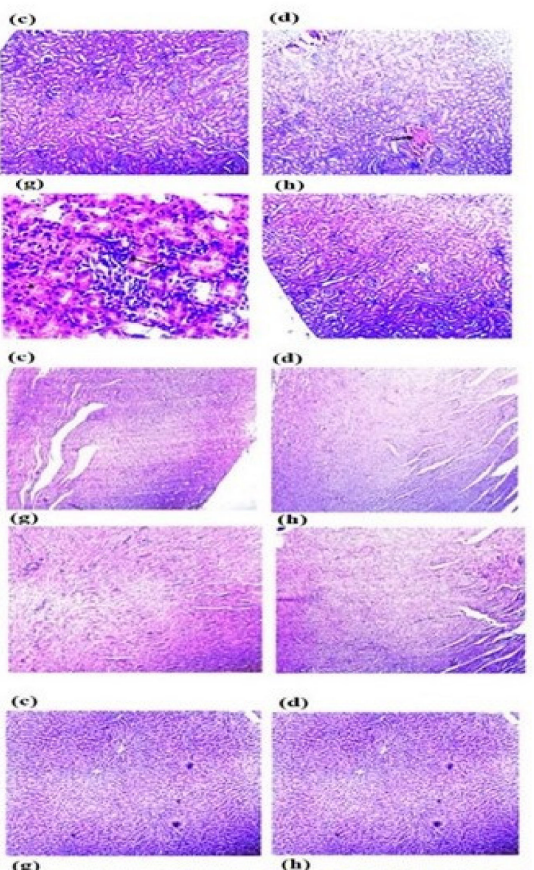

(b)
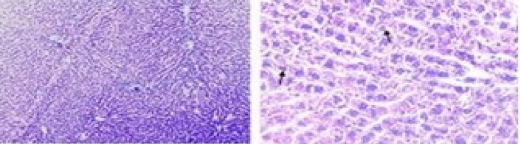

Figure 5. Photomicrographs of; (A). Kidney (B). Heart (C). Liver, section of rats from different groups following 28 days repeated oral exposure to biosynthesized ZnO NPsAL. (a) Control group (b) $0.01 \mathrm{M}$ ZnO NPsAL ( $\left.80 \mathrm{mg} \mathrm{kg}^{-1}\right)$ (c) $0.01 \mathrm{M} \mathrm{ZnO} \mathrm{NPsAL}\left(40 \mathrm{mg} \mathrm{kg}^{-1}\right)$ (d) $0.05 \mathrm{M} \mathrm{ZnO} \mathrm{NPsAL}\left(80 \mathrm{mg} \mathrm{kg}^{-1}\right)$ (e) $0.05 \mathrm{M} \mathrm{ZnO} \mathrm{NPsAL}\left(40 \mathrm{mg} \mathrm{kg}^{-1}\right)$ (f) $0.1 \mathrm{M} \mathrm{ZnO} \mathrm{NPsAL}\left(80 \mathrm{mg} \mathrm{kg}^{-1}\right)$ (g) $0.1 \mathrm{M} \mathrm{ZnO} \mathrm{NPsAL}$ $\left(40 \mathrm{mg} \mathrm{kg}^{-1}\right.$ ) (h) Zinc nitrate solution with different concentrations at $0.01 \mathrm{M}, 0.05 \mathrm{M}$ and $0.1 \mathrm{M}$. (Hematoxylin and eosin stain $\times 100$ ). Abbreviations: ZnO NPsAL; Zinc oxide nanoparticles.

Table 2. The summary of histopathological examination of renal, cardiac and hepatic tissues.

\begin{tabular}{|c|c|c|c|c|}
\hline Group & Concentration & Kidney & Heart & Liver \\
\hline A & Control & Intact tissue morphology & Intact tissue morphology & Intact tissue morphology \\
\hline B1 & $0.01 \mathrm{M} 80 \mathrm{mg} \mathrm{kg}^{-1}$ & Intact tissue morphology & Intact tissue morphology & Intact tissue morphology \\
\hline B2 & $0.01 \mathrm{M}^{4} 40 \mathrm{mg} \mathrm{kg}^{-1}$ & Intact tissue morphology & Intact tissue morphology & Intact tissue morphology \\
\hline $\mathrm{C} 1$ & $0.05 \mathrm{M} 80 \mathrm{mg} \mathrm{kg}^{-1}$ & Vascular congestion & Intact tissue morphology & Cytoplasmic vacuolation \\
\hline $\mathrm{C} 2$ & $0.05 \mathrm{M} 40 \mathrm{mg} \mathrm{kg}^{-1}$ & $\begin{array}{l}\text { Inflammation, necrosis, and } \\
\text { desquamation of } \\
\text { renal epithelium }\end{array}$ & Intact tissue morphology & Cytoplasmic vacuolation \\
\hline D1 & $0.1 \mathrm{M} 80 \mathrm{mg} \mathrm{kg}^{-1}$ & $\begin{array}{l}\text { Peritubular inflammation } \\
\text { and necrosis }\end{array}$ & Intact tissue morphology & Periportal inflammation \\
\hline D2 & $0.1 \mathrm{M} 40 \mathrm{mg} \mathrm{kg}^{-1}$ & Renal tubular necrosis & Intact tissue morphology & $\begin{array}{c}\text { Periportal inflammation } \\
\text { and fibrosis }\end{array}$ \\
\hline $\mathrm{E}$ & $\mathrm{Zn}\left(\mathrm{NO}_{3}\right)_{2}$ & Intact tissue morphology & Intact tissue morphology & Intact tissue morphology \\
\hline
\end{tabular}




\section{Discussion}

Researchers have increasingly interested in biologically synthesized metal-oxide nanostructures, especially biosynthesized ZnO NPs, due to their high reactivity, high surface volume, effective interaction with cell membranes, and controlled fabrication with cheap and harmless materials [17]. However, understanding the effect of ZnO NPs on biochemical indices and mechanism of action in the biological system still remain insufficient and is of great concern [18]. Therefore, the present study evaluated the effect of biosynthesized (ZnO NPsAL) on Wistar rat's body weight and metabolic profile, and histopathological examinations of the kidney, heart, and liver of the treated and control rats were also reported following 28 constitutive days oral administration.

Biosynthesized ZnO NPsAL oral exposure revealed a significant decrease with increasing concentrations of the nanoparticles on the bodyweight of the rats following 28 days oral exposure ( $p<0.05 ; n \geq 5$; Figure 4 ), and it could be as a result of a toxic effect of the nanoparticle that is usually associated with bodyweight alteration $[19,20]$. Similarly, studies reported significant reductions with increased concentration in the average weights of treated rats relative following 14 and 30 days oral exposure to zinc oxide and Silver/Gold nanoparticles, respectively [21].

The results revealed significant alteration on serum level markers (ALP, AST, and ALT) of liver function in rats following 28 days of oral exposure to various concentrations of biosynthesized ZnO NPs (Table 1). The liver is a vital organ that carried out detoxification, metabolism, xenobiotics extraction, and glucose storage [22]. The ALT, ALP, and AST are the reliable 'markers' of liver damage and can thus assess liver tissue necrosis [23,24]. Lee et al. (2014) reported increased serum ALP and ALT levels with increased metallic ZnO NPs concentration, similar to the result we obtained [25]. Similarly, higher doses of $\mathrm{ZnO}$ NPs were reported to increase ALP level with increasing concentration, and the increase is most likely due to liver injury inflammation produced by the nanoparticles [26].

Serum creatinine, urea, total bilirubin, and direct bilirubin were altered in rats following 28 days of oral exposure to various concentrations of biosynthesized ZnO NPs (Figure 5). AgNPs decreased serum CREA, Urea, and BIL in streptozocin-induced diabetic rats following 28 days of oral exposure [1]. Similarly, serum urea and BIL alteration were reported following daily oral exposure of $\mathrm{Au} / \mathrm{Ag}$ NPs for 30 days. The decrease in urea could be a result of a decrease in amino acid degradation by the liver, considering the decrease in the level of rat serum albumin [27]. The study revealed that increased red blood cell hemolysis could cause elevated bilirubin level beyond the hepatic function capacity [20].

In contrast, rat serum protein levels significantly decrease when treated with $0.05 \mathrm{M}$ ZnNAPsAL, whereas albumin and globulin levels remain normal in all treated groups relative to control (Figure 6). Protein levels decrease significantly in rats with Au/Ag NPs following 30 days of daily oral administration through the gavage method [27]. Similarly, inhalation exposure to ZnO NPs significantly decreased total protein in rats. It could be due to nanoparticle interaction with proteins that interfere with free radicals scavenging enzymes, leading to free radicals and necrosis [28]. Moreover, TC, HDL, TG, and LDL were also significantly increased in all treated groups compared with untreated groups (Figure 7).

Similarly, the study revealed a significant elevation of LDL, TC, and TG in Wistar rat-treated Ag NPs in a concentration-dependent manner [29]. An increase in TG and LDL levels could lead to atherosclerosis and other related cardiovascular disorders [29]. The disparities in TC, HDL, and TG serum levels could be the leading cause of several health diseases due to their essential role in the system [30].

Histopathological examination of rat renal, cardiac, and hepatic tissues following 28 days of repeated oral exposure to various concentrations of biosynthesized ZnO NPsAL showed alteration in the morphology of all the tissues with increased biosynthesized $\mathrm{ZnO}$ NPs concentration. Intact morphology was observed in control groups A, B1, B2, and E, and vascular congestion, inflammation, and necrosis were observed in groups C1, C2, D1, 
and D3. The intact morphology observed in the group treated with zinc nitrate solution and $0.01 \mathrm{M}$ solution might result from fewer $\mathrm{Zn}$ ions present in the solution. In addition, morphological alteration observed in the groups treated $0.05 \mathrm{M}$ and $0.1 \mathrm{M}$, which might be as a result of the increase in the concentration of Zinc ions present in the solution, and a similar concentration-dependent effect was observed in liver and kidney tissues of rats treated with $\mathrm{ZnO}$ nanoparticles [31].

Histopathological analysis of renal tissue of rats treated with various concentrations of biosynthesized $\mathrm{ZnO}$ NPsAL revealed vascular congestion, inflammation, necrosis, and desquamation of renal epithelium (Figure 8a). Glomeruli segmentation, hydropic degeneration in epithelial cells, necrosis, and swelling of epithelial cells were observed in the kidney tissues of mice treated with ZnO NPs [32]. Peritubular inflammation observed in our studies results from progressive chronic kidney diseases like renal tubule interstitial fibrosis, tubular cell differentiation, epithelial-mesenchymal transition, and myofibroblast activation [33,34]. Intact cardiac tissue morphology was observed in all the groups treated with various concentrations of biosynthesized ZnO NPs and the control (Figure 8b).

Similarly, a high concentration of ZnO NPs did not reveal any cellular damage in the cardiac tissue of rats following 30 days of exposure [35]. A study conducted on cardiac tissue of rats exposed to metallic Ag/ Au NPs at a dose of $100 \mathrm{mg} \mathrm{kg}^{-1}$ for 30 days revealed cellular degeneration and inflammation of the cardiac tissue [27]. Studies showed that NPs induced oxidative tissue damage due to their small sizes and unique properties [36]. Morphological changes were observed in the liver tissues with increased concentration of the NPs as revealed in the liver tissue architecture of the rats, and they might be responsible for inducing apoptosis [37]. A study on the liver tissue morphology in rats treated with $\mathrm{ZnO}$ NPs (50 $\mathrm{nm}$ ) revealed morphological alterations and mitochondria disorders [38]. Similarly, accumulation of ZnO NPs in the hepatic tissue was observed in mice after eight days of exposure to ZnO NPs at the dose of $300 \mathrm{mg} \mathrm{kg}^{-1}$ [39,40]. Furthermore, a study on zinc and iron NPs has revealed an adverse morphological effect on rat liver tissue [41].

\section{Materials and Methods}

\subsection{Chemicals}

All chemical and reagents used throughout the experiment were of analytical grade and were supplied by Sigma Aldrich Inc., St. Louis, USA, unless otherwise mentioned. Zinc nitrate, zinc nitrate $\left(\mathrm{Zn}\left(\mathrm{NO}_{3}\right)_{2} \cdot 6 \mathrm{H}_{2} \mathrm{O}\right)$ solutions. Ketamine and xylazine for the anesthesia. The assay kits for Total Cholesterol (TC), Triacyglycerols (TG), High-Density Lipoprotein (HDL-C), Creatinine (CREA), Urea, Bilirubin (BIL), Albumin (ALB), Alkaline Phosphatase (ALP), Alanine Aminotransferase (ALT), and Aspartate Aminotransferase (AST) (Randox Laboratory Limited, Antrim, United Kingdom). Deionized water was used for the preparation of the biosynthesized ZnO NPsAL.

\subsection{Synthesis of Zinc Oxide Nanoparticles}

$\mathrm{ZnO}$ NPs using $A$. lebbeck aqueous extract (ZnO NPsAL) was prepared using the method employed by Zare et al. with some minor modifications [42]. Synthesis of $\mathrm{ZnO}$ NPs was carried out using 10\% 0.1, 0.05 and $0.01 \mathrm{M}$ zinc nitrate $\left(\mathrm{Zn}\left(\mathrm{NO}_{3}\right)_{2} \cdot 6 \mathrm{H}_{2} \mathrm{O}\right)$ solutions and $90 \%$ distilled water; then, $10 \%$ A. lebbeck aqueous extract was added dropwise to the mixture under constant shaking/stirring at a temperature of $60{ }^{\circ} \mathrm{C}$ for five consecutive hours so that we can achieve complex formation. After the complex was formed, the mixtures were calcined for $2 \mathrm{~h}$ at $350{ }^{\circ} \mathrm{C}$ in a muffle furnace.

\subsection{Characterization of Biosynthesized Zinc Oxide Nanoparticles}

The biosynthesized ZnO NPsAL ZnO NPs were characterized using various spectroscopic and microscopic techniques. A UV-visible spectrophotometer (Shimadzu UV-2450, Duisberg, Germany) was used to evaluate the UV-visible spectrum and recorded between 300 and 800nm (Figure 6). The crystalline structure was analyzed using an X-ray diffractometer (Rigaku ZSX Primus II, Wilmington, MA, USA) (Figure 7). Morphological analysis 
of the synthesized ZnO NPs coated with platinum was analyzed using a scanning electron microscope (SEM) (JOEL JSM 6335-F, Tokyo, Japan), X-ray spectroscopy (EDS) (Oxford Instruments AZTEC EDS, Osaka, Japan) affixed to the same instrument was used to ascertain the elemental composition (Figure 8). Size of the synthesized nanoparticles was evaluated using the Malvern Zetasizer Nano ZS90 instrument. The average size of the nanoparticles was found to be $66.25 \mathrm{~nm}$ with a 0.262 polydispersity index (Figure 9). Uv-Vis, XRD, and SEM-EDS, and Zeta sizer results of biosynthesized ZnO NPsAL were previously reported in our recent studies [10].

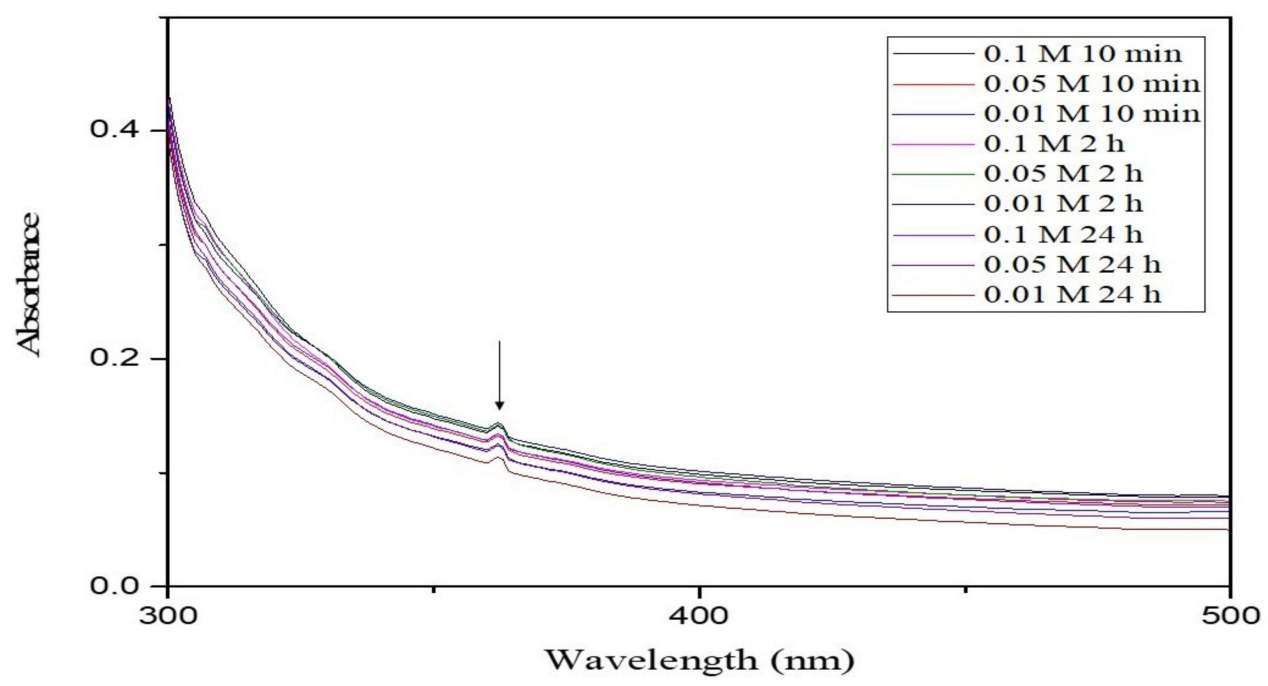

Figure 6. UV-visible spectra of biosynthesized ZnO NPsAL prepared with various concentrations of zinc nitrate at different wavelengths and incubation periods. Adapted from Umar et al. (2019) [19].

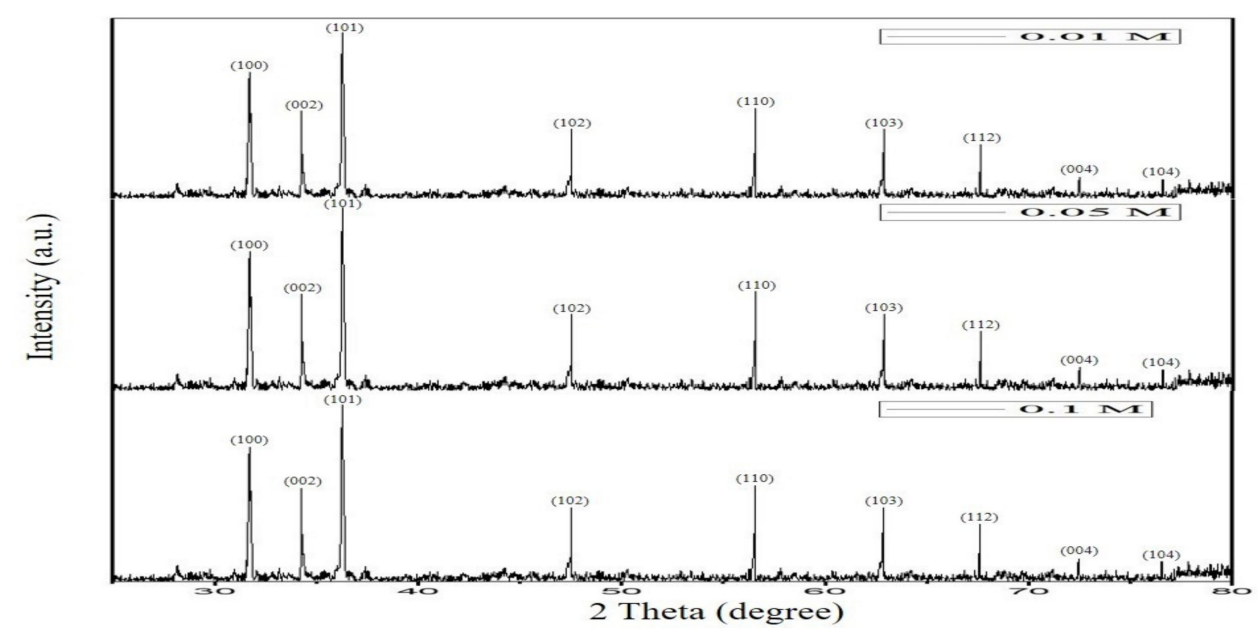

Figure 7. XRD pattern of $0.01 \mathrm{M}, 0.05 \mathrm{M}$, and $0.1 \mathrm{M}$ biosynthesized $\mathrm{ZnO}$ NPsAL. Adapted from Umar et al. (2019) [19]. 

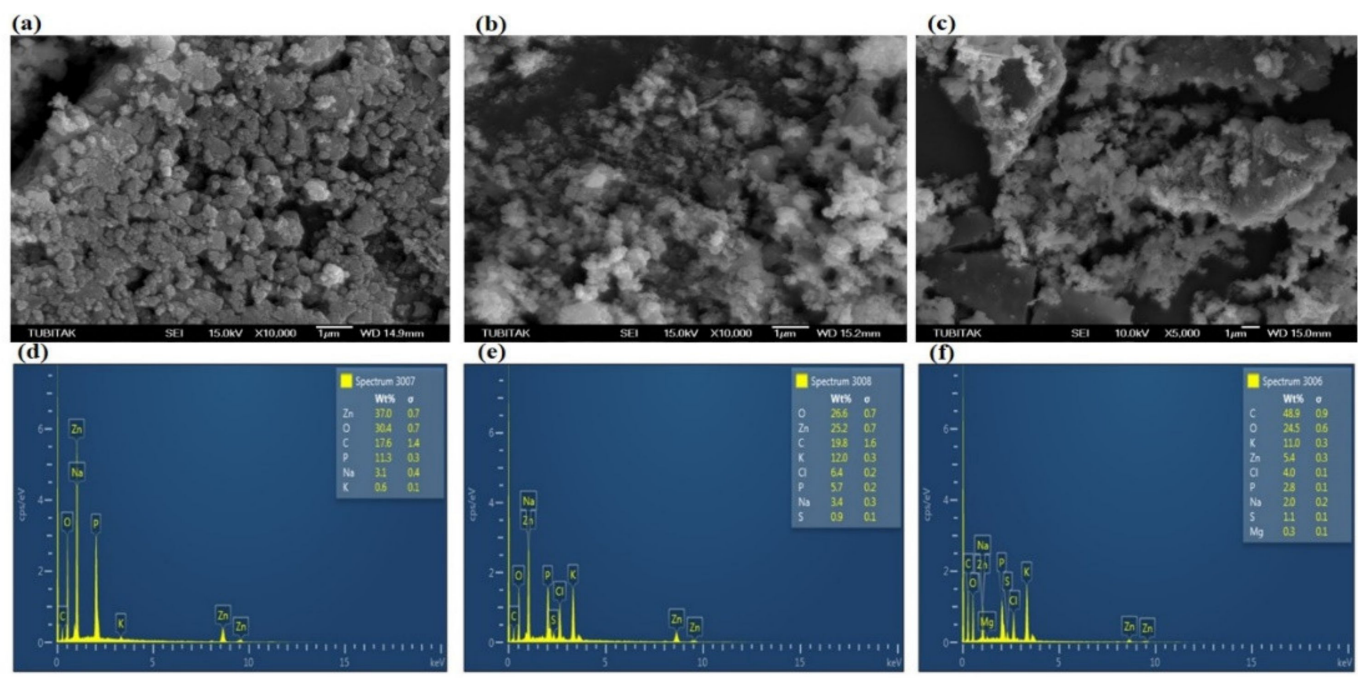

Figure 8. SEM images of biosynthesized ZnO NPsAL: (a) $0.1 \mathrm{M}$, (b) $0.05 \mathrm{M}$, and (c) $0.01 \mathrm{M}$. EDX spectra of the ZnO NPs: (d) $0.1 \mathrm{M}$, (e) $0.05 \mathrm{M}$, and (f) $0.01 \mathrm{M}$. Adapted from Umar et al. (2019) [19].
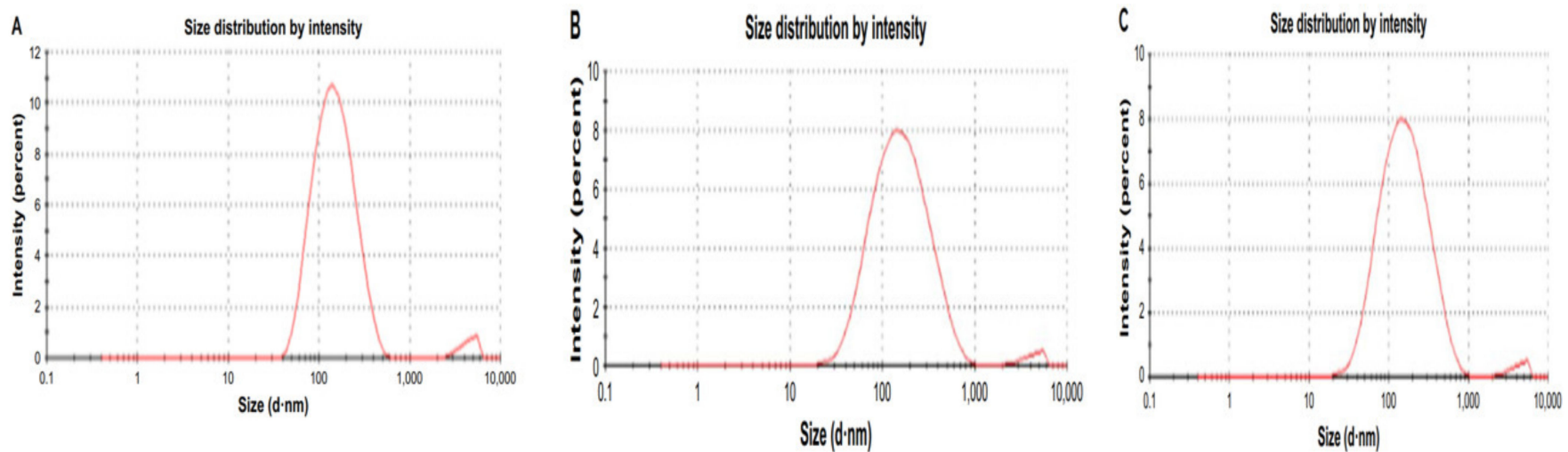

Figure 9. Size of the synthesized ZnO NPs nanoparticle and its distribution (A) $0.1 \mathrm{M}$ (B) $0.05 \mathrm{M}$ and (C) $0.01 \mathrm{M}$. Hydrodynamic size of the synthesized nanoparticles was analyzed using the Zeta sizer (ZS) analytical instrument (Malvern Nano ZS90), and the results were obtained using ZS290 nano software coupled with the device. Adapted from Umar et al. (2019) [19].

\subsection{Experimental Animals}

Albino Wistar rats weighed $170 \pm 5 \mathrm{~g}$ from the Biological Science Department's animal house, Bayero University, Kano. The animals were kept in plastic cages in the experimental animal house and allowed to acclimatize for two weeks before the commencement of treatments. Animals were maintained under standard hygienic conditions with alternate $12 \mathrm{~h}$ light and dark cycle. Animals were given free access to food and clean water ad libitum. Handling of animals was consistent with relevant guidelines on the care and use of laboratory animals (National Research Council 2011). They were sustained throughout the experimental period in conformity with the Ethics Committee of Bayero University, Kano.

\subsection{Experimental Design and Treatments}

Adult Rats were randomly classified into eight groups of five rats each and they were treated with $0.5 \mathrm{ml}$ of the biosynthesized ZnO NPsAL and zinc nitrate daily by gavage method (Sulaiman et al., 2015) for 28 constitutive days as follows: Group A, normal control group, fed with normal diet and water for 28 days; Group B1, administered with $0.01 \mathrm{M}$ biosynthesized ZnO NPsAL ( $80 \mathrm{mg} / \mathrm{kg}$ ); Group B2, administered with $0.01 \mathrm{M}$ biosynthesized ZnO NPsAL (40 mg/kg); Group C1, administered with $0.05 \mathrm{M}$ biosynthesized ZnO 
NPsAL (80 mg/kg); Group C2, administered with $0.05 \mathrm{M}$ biosynthesized ZnO NPsAL (40 mg/kg); Group D1, administered with $0.1 \mathrm{M}$ biosynthesized ZnO NPsAL (80 mg/kg); Group D2, administered with 0.1 M biosynthesized ZnO NPsAL (40 mg/kg); Group E, administered with $10 \%$ Zinc nitrate solution $(80 \mathrm{mg} / \mathrm{kg})$. The amount of Zinc nitrate solution used has the same concentration as the amount of Zinc nitrate solution used in the synthesis of the nanoparticle.

\subsection{Blood Sampling and Tissue Preparation}

The rats were weighed, anesthetized with $60 / 6 \mathrm{mg} / \mathrm{kg}$ of ketamine/xylazine intraperitoneally $24 \mathrm{~h}$ after the last treatment. Blood samples were taken in a clean and sterile sample container. The serum was obtained after the blood sample was centrifuged at $3000 \mathrm{rpm}$ for $15 \mathrm{~min}$ stored at $-80{ }^{\circ} \mathrm{C}$ prior to analysis. The rats were sacrificed and kidney, heart, and liver tissues were separated, weighed, and kept in $10 \%$ formaldehyde prior to histopathological examinations.

\subsection{Biochemical Parameters Analysis}

The serum levels of AST, ALT, ALP, ALB, BIL, CREA, urea, serum TC concentration, HDL-C, and TG were assayed using the Randox assay kits (Randox Laboratory Limited County Antrim, United Kingdom) according to the manufacturer's instructions. The concentration of serum LDL-C was estimated using the Fried Ewald formula [43]. The protein content of the serum was determined using the biuret method as previously described by [44].

\subsection{Histopathological Examination}

Kidney, heart, and liver tissue fragments were removed and fixed with $10 \%$ formaldehyde, dehydrated with ascending grade of alcohol, cleared with toluene, infiltrated with molten paraffin wax. The microtone section was stained with the hematoxylin and eosin (H\&E) staining technique, mounted in mounting media and examined with a Leica DM 750 microscope, and photographed with Leica 1CC 50 HD Camera.

\subsection{Statistical Analysis}

Data are given as means \pm standard errors of the mean (SEMs). Statistical comparisons were carried out using one-way analysis of variance (ANOVA) followed by Newman-Keuls post hoc analysis where necessary on SPSS version 23 software. The significance levels were set up at the $5 \%, 1 \%$, and $0.1 \%$ levels, where $p<0.05$ was considered significant, $p<0.01$ insignificant and $p<0.0001$ considered highly significant.

\section{Conclusions}

The present study demonstrated the effect of various concentrations of ZnO NPs synthesized using Albizia lebbeck stem bark extract as a chelating agent on biochemical parameters and tissue morphology in Wistar rats. Biosynthesized ZnO NPs caused a significant alteration in rats' mean body weight, serum alkaline phosphatase, alanine aminotransferase, creatinine, urea, bilirubin, protein, albumin, globulin, total cholesterol, triacylglycerol, low density, and high-density lipoprotein in a concentration-dependent manner. Additionally, histopathological analysis of treated rats' kidney, heart, and liver tissue revealed vascular congestion, tubular necrosis, inflammation, and cytoplasmic vacuolation.

Author Contributions: D.K., A.L.A., N.R. and H.U. contributed to the design and implementation of the research, to the analysis of the results and to the writing of the manuscript. All authors have read and agreed to the published version of the manuscript.

Funding: This research received no external funding.

Institutional Review Board Statement: Handling of animals was consistent with relevant guidelines on the care and use of laboratory animals (National Research Council 2011). They were sustained 
throughout the experimental period in conformity with the Ethics Committee of Bayero University, Kano.

Informed Consent Statement: "Not applicable" for studies not involving humans.

Data Availability Statement: The authors confirm that the data supporting the findings of this study are available within the article.

Acknowledgments: The present study was supported by Cyprus International University, Biotechnology Research Centre, Cyprus, Nicosia, 2020. The authors will like to thank Cyprus International University for their support.

Conflicts of Interest: The authors declare no conflict of interest.

$\begin{array}{ll}\text { Abbreviations } \\ \text { ZnO NPs } & \text { zinc oxide nanoparticles } \\ \text { NPs } & \text { nanoparticles } \\ \text { ZnO NPsAL } & \text { Zinc oxide nanoparticles synthesized using A. lebbeck stem extract } \\ \text { FDA } & \text { food and drug administration } \\ \text { ALP } & \text { alkaline phosphatase } \\ \text { ALT } & \text { alanine aminotransferase } \\ \text { AST } & \text { aspartate aminotransferase } \\ \text { CREA } & \text { creatinine } \\ \text { TBIL } & \text { total bilirubin } \\ \text { DBIL } & \text { Direct bilirubin } \\ \text { TC } & \text { Total Cholesterol } \\ \text { TG } & \text { Triacylglycerols } \\ \text { HDL-C } & \text { High Density Lipoprotein } \\ \text { ALB } & \text { Albumin } \\ \text { GLB } & \text { Globulin } \\ \text { Uv-Vis } & \text { UV-visible spectrophotometer } \\ \text { XRD } & \text { X-ray diffractometer } \\ \text { SEM } & \text { scanning electron microscope } \\ \text { EDS } & \text { X-ray spectroscopy } \\ \text { A } & \text { normal control group } \\ \text { B1 } & \text { treated with } 0.01 \mathrm{M} \text { ZnO NPsAL }\left(80 \mathrm{mg} \mathrm{kg}^{-1}\right) \\ \text { B2 } & \text { treated with } 0.01 \mathrm{M} \text { ZnO NPsAL }\left(40 \mathrm{mg} \mathrm{kg}^{-1}\right) \\ \text { C1 } & \text { treated with } 0.05 \mathrm{M} \text { ZnO NPsAL }\left(80 \mathrm{mg} \mathrm{kg}^{-1}\right) \\ \text { C2 } & \text { treated with } 0.05 \mathrm{M} \text { ZnO NPsAL }\left(40 \mathrm{mg} \mathrm{kg}^{-1}\right) \\ \text { D1 } & \text { treated with } 0.1 \mathrm{M} \text { ZnO NPsAL }\left(80 \mathrm{mg} \mathrm{kg}^{-1}\right) \\ \text { D2 } & \text { treated with } 0.1 \mathrm{M} \text { ZnO NPsAL }\left(40 \mathrm{mg} \mathrm{kg}^{-1}\right) \\ \text { E } & \text { treated with Zinc nitrate solution }\left(80 / 40 \mathrm{mg} \mathrm{kg}^{-1}\right) \\ & \end{array}$

\section{References}

1. Khan, Z.U.H.; Khan, A.; Chen, Y.; Shah, N.S.; Muhammad, N.; Khan, A.U.; Tahir, K.; Khan, F.U.; Murtaza, B.; Hassan, S.U.; et al. Biomedical applications of green synthesized Nobel metal nanoparticles. J. Photochem. Photobiol. B Biol. 2017, 173, 150-164. [CrossRef] [PubMed]

2. Tabrez, S.; Musarrat, J.; Al-khedhairy, A.A. biointerfaces countering drug resistance, infectious diseases, and sepsis using metal and metal oxides nanoparticles: Current status. Colloids Surf. B Biointerfaces 2016, 146, 70-83.

3. Pardeshi, S.K.; Patil, A.B. Effect of morphology and crystallite size on solar photocatalytic activity of zinc oxide synthesized by solution free Mechano chemical method. J. Mol. Catal. A Chem. 2009, 308, 32-40. [CrossRef]

4. Mittal, A.K.; Chisti, Y.; Banerjee, U.C. Synthesis of metallic nanoparticles using plant extracts. Biotechnol. Adv. 2013, 31, 346-356. [CrossRef] [PubMed]

5. Rasmussen, J.W.; Martinez, E.; Louka, P.; Wingett, D.G. Zinc oxide nanoparticles for selective destruction of tumor cells and potential for drug delivery applications. Expert Opin. Drug Deliv. 2010, 7, 1063-1077. [CrossRef] [PubMed]

6. Gaharwar, A.; Peppas, N.A.; Khademhosseini, A. Nanocomposite hydrogels for biomedical applications. Biotechnol. Bioeng. 2014, 111, 441-453. [CrossRef]

7. Jansen, J.; Karges, W.; Rink, L. Zinc and diabetes-Clinical links and molecular mechanisms. J. Nutr. Biochem. 2009, 20, 399-417. [CrossRef] 
8. Saif, S.; Tahir, A.; Chen, Y. Green synthesis of iron nanoparticles and their environmental applications and implications. Nanomaterials 2016, 6, 209. [CrossRef]

9. Suresh, J.; Pradheesh, G.; Alexramani, V.; Sundrarajan, M.; Hong, S.I. Green synthesis and characterization of zinc oxide nanoparticle using insulin plant (Costus pictus D. Don) and investigation of its antimicrobial as well as anticancer activities. Adv. Nat. Sci. Nanosci. Nanotechnol. 2018, 9, 015008. [CrossRef]

10. Rajiv, P.; Rajeshwari, S.; Venckatesh, R. Bio-Fabrication of zinc oxide nanoparticles using leaf extract of Parthenium hysterophorus L. and its size-dependent antifungal activity against plant fungal pathogens. Spectrochim. Acta Part A Mol. Biomol. Spectrosc. 2013, 112, 384-387. [CrossRef]

11. Umar, H.; Kavaz, D.; Rizaner, N. Biosynthesis of zinc oxide nanoparticles using Albizia lebbeck stem bark, and evaluation of its antimicrobial, antioxidant, and cytotoxic activities on human breast cancer cell lines. Int. J. Nanomed. 2018, 14, 87-100. [CrossRef]

12. El-Gharbawy, R.M.; Emara, A.M.; Abu-Risha, S.E.-S. Zinc oxide nanoparticles and a standard antidiabetic drug restore the function and structure of beta cells in Type-2 diabetes. Biomed. Pharmacother. 2016, 84, 810-820. [CrossRef]

13. Kavaz, D.; Umar, H.; Zimuto, T. Biosynthesis of gold nanoparticles using Scytosiphon lomentaria (Brown algae) and Spyridia filamentosa (Red algae) from Kyrenia Region and evaluation of their antimicrobial and antioxidant activity. Hacet. J. Biol. Chem. 2019. [CrossRef]

14. Al-Massarani, S.M.; El Gamal, A.A.; El Halim, M.F.A.; Al-Said, M.S.; Abdel-Kader, M.S.; Basudan, O.A.; Alqasoumi, S.I. New acyclic secondary metabolites from the biologically active fraction of Albizia lebbeck flowers. Saudi Pharm. J. 2017, 25, 110-119. [CrossRef]

15. Islam, S.; Shajib, S.; Datta, B.K.; Rashid, M.A. Neuropharmacological activities of methanol extract of Albizia lebbeck (L.) benth. Bangladesh Pharm. J. 2018, 21, 80-86. [CrossRef]

16. Ahmed, D.; Kumar, V.; Sharma, M.; Verma, A. Target guided isolation, in-vitro antidiabetic, antioxidant activity and molecular docking studies of some flavonoids from Albizzia lebbeck Benth. bark. BMC Complement. Altern. Med. 2014, 14, 155. [CrossRef]

17. Cruz, D.M.; Mostafavi, E.; Vernet-Crua, A.; Barabadi, H.; Shah, V.; Cholula-Díaz, J.L.; Guisbiers, G.; Webster, T.J. Green nanotechnology-based zinc oxide (ZnO) nanomaterials for biomedical applications: A review. J. Phys. Mater. 2020, 3, 034005. [CrossRef]

18. Adeyemi, O.S.; Sulaiman, F.A.; Akanji, M.A.; Oloyede, H.O.B.; Olatunde, A.; Salman, S.T.; Aransiola, A.R.; Ajayi, A.G.; Ekundayo, M.M.; Abubakar, F.A.; et al. Biochemical and morphological changes in rats exposed to platinum nanoparticles. Comp. Haematol. Int. 2016, 25, 855-864. [CrossRef]

19. Orisakwe, O.E.; Husaini, D.C.; Afonne, O.J. Testicular effects of sub-chronic administration of Hibiscus sabdariffa calyx aqueous extract in rats. Reprod. Toxicol. 2004, 18, 295-298. [CrossRef]

20. Sulaiman, F.A.; Adeyemi, O.; Akanji, M.A.; Oloyede, H.O.B.; Sulaiman, A.A.; Olatunde, A.; Hoseni, A.A.; Olowolafe, Y.V.; Nlebedim, R.N.; Muritala, H.; et al. Biochemical and morphological alterations caused by silver nanoparticles in Wistar rats. J. Acute Med. 2015, 5, 96-102. [CrossRef]

21. Torabi, F.; Shafaroudi, M.M.; Rezaei, N. Combined protective effect of zinc oxide nanoparticles and melatonin on cyclophosphamide-induced toxicity in testicular histology and sperm parameters in adult Wistar rats. Int. J. Reprod. Biomed. 2017, 15, 403-412. [CrossRef]

22. Francis, G.A.; Fayard, E.; Picard, F.; Auwerx, J. Nuclear receptors and the control of metabolism. Annu. Rev. Physiol. 2003, 65, 261-311. [CrossRef] [PubMed]

23. Adeyemi, O.; Adewumi, I. Biochemical evaluation of silver nanoparticles in wistar rats. Int. Sch. Res. Not. 2014, 2014, 1-8. [CrossRef]

24. Sheth, S.G.; Flamm, S.L.; Gordon, F.D.; Chopra, S. AST / ALT ratio predicts cirrhosis in patients with chronic hepatitis C virus infection. Am. J. Gastroenterol. 1998, 93, 44-48. [CrossRef]

25. Lee, J.-W.; Kim, J.-E.; Shin, Y.-J.; Ryu, J.-S.; Eom, I.-C.; Lee, J.S.; Kim, Y.; Kim, P.-J.; Choi, K.-H.; Lee, B.-C. Serum and ultrastructure responses of common carp (Cyprinus carpio L.) during long-term exposure to zinc oxide nanoparticles. Ecotoxicol. Environ. Saf. 2014, 104, 9-17. [CrossRef]

26. Jeong, J.; Kim, J.; Seok, S.H.; Cho, W.-S. Indium oxide $\left(\mathrm{In}_{2} \mathrm{O}_{3}\right)$ nanoparticles induce progressive lung injury distinct from lung injuries by copper oxide $(\mathrm{CuO})$ and nickel oxide $(\mathrm{NiO})$ nanoparticles. Arch. Toxicol. 2015, 90, 817-828. [CrossRef]

27. Sulaiman, F.; Akanji, M.; Oloyede, H.; Olatunde, A.; Joel, E.; Adewale, T.; Adeboye, H.; Idris, S.; Quadri, A.; Oyegoke, R.; et al. Oral exposure to silver/gold nanoparticles: Status of rat lipid profile, serum metabolites and tissue morphology. J. Med. Sci. 2015, 15, 71-79. [CrossRef]

28. Schrand, A.M.; Rahman, M.F.; Hussain, S.M.; Schlager, J.J.; Smith, D.A.; Syed, A.F. Metal-based nanoparticles and their toxicity assessment. Wiley Interdiscip. Rev. Nanomed. Nanobiotechnol. 2010, 2, 544-568. [CrossRef] [PubMed]

29. Beishuizen, C.R.L.; Stephan, B.C.M.; Van Gool, W.A.; Brayne, C.; Peters, R.J.G.; Andrieu, S.; Kivipelto, M.; Soininen, H.; Busschers, W.B.; Van Charante, E.P.M.; et al. Web-based interventions targeting cardiovascular risk factors in middle-aged and older people: A systematic review and meta-analysis. J. Med. Internet Res. 2016, 18, e55. [CrossRef]

30. Adeyemi, O.S.; Sulaiman, F.A. Co-administration of iron sulphate and nitroglycerin promoted oxidative stress and mild tissue damage in Wistar rats. Comp. Haematol. Int. 2013, 23, 1525-1533. [CrossRef]

31. Hua-Qiao, T.; Min, X.; Qian, R.; Ru-Wen, J.; Qi-Ji, L.; Li, Y.-L. The effect of ZnO nanoparticles on liver function in rats. Int. J. Nanomed. 2016, 11, 4275-4285. [CrossRef] 
32. Liu, J.-H.; Ma, X.; Xu, Y.; Tang, H.; Yang, S.-T.; Yang, Y.-F.; Kang, D.-D.; Wang, H.; Liu, Y. Low toxicity and accumulation of zinc oxide nanoparticles in mice after 270-day consecutive dietary supplementation. Toxicol. Res. 2017, 6, 134-143. [CrossRef]

33. Boor, P.; Ostendorf, T.; Floege, J. Renal fibrosis: Novel insights into mechanisms and therapeutic targets. Nat. Rev. Nephrol. 2010, 6, 643-656. [CrossRef]

34. Fischer, R.S.; Vangala, C.; Truong, L.; Mandayam, S.; Chavarria, D.; Llanes, O.M.G.; Laguna, M.U.F.; Baez, A.G.; Garcia, F.; García-Trabanino, R.; et al. Early detection of acute tubulointerstitial nephritis in the genesis of Mesoamerican nephropathy. Kidney Int. 2018, 93, 681-690. [CrossRef]

35. Ben Slama, I. Sub-Acute Oral Toxicity of Zinc Oxide Nanoparticles in Male Rats. J. Nanomed. Nanotechnol. 2015, 6. [CrossRef]

36. Hudecová, A.; Kusznierewicz, B.; Rundén-Pran, E.; Magdolenová, Z.; Hašplová, K.; Rinna, A.; Fjellsbø, L.M.; Kruszewski, M.; Lankoff, A.; Sandberg, W.J.; et al. Silver nanoparticles induce premutagenic DNA oxidation that can be prevented by phytochemicals from Gentiana asclepiadea. Mutagenesis 2012, 27, 759-769. [CrossRef]

37. Ahamed, M.; Ali, D.; Alhadlaq, H.; Akhtar, M.J. Nickel oxide nanoparticles exert cytotoxicity via oxidative stress and induce apoptotic response in human liver cells (HepG2). Chemosphere 2013, 93, 2514-2522. [CrossRef]

38. Shrivastava, R.; Kushwaha, P.; Bhutia, Y.C.; Flora, S. Oxidative stress following exposure to silver and gold nanoparticles in mice. Toxicol. Ind. Health 2014, 32, 1391-1404. [CrossRef]

39. Effects of zinc oxide nanoparticles on renal function in mice. Int. J. Biosci. 2014, 5. [CrossRef]

40. Paek, H.-J.; Lee, Y.-J.; Chung, H.-E.; Yoo, N.-H.; Lee, J.-A.; Kim, M.-K.; Lee, J.K.; Jeong, J.; Choi, S.-J. Modulation of the pharmacokinetics of zinc oxide nanoparticles and their fates in vivo. Nanoscale 2013, 5, 11416-11427. [CrossRef]

41. Wang, L.; Wang, L.; Ding, W.; Zhang, F. Acute Toxicity of Ferric Oxide and Zinc Oxide Nanoparticles in Rats. J. Nanosci. Nanotechnol. 2010, 10, 8617-8624. [CrossRef]

42. Zare, E.; Pourseyedi, S.; Khatami, M.; Darezereshki, E. Simple biosynthesis of zinc oxide nanoparticles using nature's source, and it's in vitro bio-activity. J. Mol. Struct. 2017, 1146, 96-103. [CrossRef]

43. Krishnaveni, P.; Gowda, V.M. Assessing the validity of friedewald's formula and anandraja's formula for serum L DL -cholesterol calculation. J. Clin. Diagn. Res. 2015, 9, BC01-BC04. [CrossRef]

44. Olivares, R.W.I.; Postma, G.; Schapira, A.; Iglesias, D.E.; Valdez, L.B.; Breininger, E.; Gazzaneo, P.D.; Minatel, L. Biochemical and morphological alterations in hearts of copper-deficient bovines. Biol. Trace Element Res. 2019, 189, 447-455. [CrossRef] 